\title{
Research on Cooperation Cultivation Model of Financial Applied Talents in Private Colleges of Finance and Economics
}

\author{
Liuyang Zhao \\ Changchun University of Finance and Economics, Changchun, 130122, China
}

Keywords: Cooperation cultivation, Financial applied talents, Private colleges of finance and economics

\begin{abstract}
With the development and the transformation of the financial industry structure of China's social and economic, many high-quality and applied financial talents are urgently needed. Private colleges of finance and economics bear the important task of training financial applied talents. This paper analyzes the characteristics of applied talents in financial specialty and gives some suggestions to strengthen the cooperation of theory and practice, cooperation of self-learning and teaching and cooperation of colleges and enterprises to provide some references for the relevant researchers.
\end{abstract}

\section{Introduction}

The development of modern financial industry needs not only talents with rich theoretical knowledge, but also higher practical ability. This requires the university financial education should combine theory and practice, application oriented Talents Cultivation teaching reform, innovative teaching mode, the development of practical teaching, the cultivation of applied talents as the goal, to cultivate more financial talents for the society. At present, many private colleges have already noticed the practice of financial teaching, and have done a lot of work. All kinds of colleges and universities according to their own strength for different degrees of investment in financial practice teaching, in teaching methods, teaching activities organization, experiment and training base construction, and school enterprise cooperation and to establish training bases such as hardware and software aspects of the reform, and achieved certain results. However, overall, from the perspective of ideas and practice, it is far from achieving the teaching effect of application-oriented talents training. Therefore, it is necessary to innovate the practical teaching mode, greatly improve the quality of teaching, and improve the comprehensive quality of students through practical teaching, so as to better meet the needs of future work. With the wide application of modern information technology and network technology in the financial industry, relying on the modern technology of financial products continue to produce more and more high technology content of financial products, to the practical operation requirements also will improve. The development of modern finance has made the research of financial theory change from macro theory to microcosmic financial behavior and market research. However, due to the operational and practical nature of the financial curriculum, the teaching of financial specialty needs to highlight the practical teaching links, and ensure that practical teaching has achieved solid results. Private financial universities should make clear their position in the higher education market, correctly understand the types and characteristics of their universities, and select the training model accurately according to the characteristics of talent training.

\section{Targets of Cooperation Cultivation of Financial Applied Talents}

Solid Theory Knowledge. Private financial training mode should adhere to the cultivation of applied talents as the starting point for the necessary job skills, knowledge, ability and quality structure of students, and through the implementation of construction innovation to achieve the 
objective of cultivating talents. In the aspect of knowledge, it requires a certain breadth of knowledge and forms a variety of knowledge structures. Students' knowledge should be a complete, systematic and scientific professional application knowledge system, with certain humanities, financial, management, interpersonal and other aspects. The current financial regulations and financial policies are very important in the actual financial operation, and directly regulate and guide the operation and innovation of the financial business. The applied financial talents are mainly in the front line of the financial business operation, and their every move is restricted by the financial laws and policies. It is precisely because of sound and sound financial laws and policies that it ensures the efficient operation of financial services and effective control of financial risks. Third, significant difference between the applied talents and ordinary operating talents is the basic theory of timely and reasonable use can carry out creative work, such as business process improvement, innovation of financial products, put forward a new way of service. This series of innovative activities must follow existing regulations and policies, it has practical significance. Especially in the case of global financial risk and the rapid spread of the international situation, each country and relevant world organizations have relatively strict laws, policies or guidelines. It is impossible for practical talents to work creatively if they are not familiar with financial laws and financial policies.

Rich Practice Experience. The best way to increase the rational knowledge and understand the operation ability of the financial market and financial business operation is to practice the simulation teaching link in the effective teaching method. Applied financial talents not only has the specific post operation ability, more should be familiar with the operation rules, the financial institutions business operation process and management process, the relationship between the unique position of understand specific position in the whole process and other aspects. We should not only know the financial business, but also know why. With this quality, we can apply theory to practice and serve the social and economic development better. One notable difference between financial application talents and skills of financial talents is the operational capacity of the former is multi sectoral, multi post, can adapt to the financial industry in all areas of business line capacity requirements, can easily transfer work in banks, securities, insurance, trusts, funds, asset management and other financial industry. At the same time, it also can work in the post savings, accounting and statistical supervision, product promotion marketing, credit investigation and review, risk control, financial services. The latter generally only have specific positions of operation technology. The business has more solid basic skills, and on this basis, the real financial situation and outlook of macro-economic and financial policies have strong observation and judgment, analysis and logical thinking ability, to perform the management work of grass-roots or middle positions. At present, many schools have set up financial comprehensive simulation laboratory teaching, but the operation software is relatively backward, so the introduction and innovation of financial system in the laboratory teaching software, stock, futures, foreign exchange investment fund, simulation analysis and Simulation of transactions become an important link to improve students' practical level.

Good Professional Ethics. The employment direction of financial professionals is generally located in banking, securities, insurance and other financial institutions, and these institutions deal with money at any time, both risk and temptation coexist. The special nature of the financial industry determines the school in the process of education to the students, not only to pay attention on professional knowledge, professional skills, but also to adhere to the ideological education of students, cultivate students with good financial occupation and strong financial occupation moral responsibility. Professional ethics is not only a basic requirement for employees in service units or trades, but also a code of conduct for practitioners. Financial industry is a special industry based on credit and specialized in credit, and it is the most extensive service industry with the most extensive audience. Therefore, it requires higher and more strict requirements for the professional ethics of financial practitioners. The practice of financial industry at home and abroad has proved that the biggest risk of financial industry has not only come from credit risk and market risk, but also from operational risk and moral risk. Applied financial talents in the first line of the financial industry, whether it has good financial occupation moral and personal integrity is the key factor in the success or failure of the cause, but also personnel training is one of the important indicators of success. 
Financial professionals are important participants in the socialist market economy in the future. We should strengthen the cultivation of credit concept of financial professionals should be the core of professional ethics education.

\section{Methods of Cooperation Cultivation of Financial Applied Talents}

Cooperation of Theory and Practice. As an important part of the teaching process, practice teaching is an important means to train students' practical ability, and an effective way and an important guarantee to achieve the goal of application-oriented talents training. The birth of finance is to meet and promote the needs of modern economic development, and its teaching content and curriculum settings should be adjusted accordingly with the development of economy. The new teaching content must incorporate the latest research results of emerging issues such as financial securitization, financial innovation and financial derivatives applications. At the same time, the corresponding research on the condition of opening financial and economic operation of the new financial products of financial market and financial system, timely new achievements of financial theoretical research into the teaching content, to meet the needs of finance theory and practice. The construction of the experimental base, it is necessary to strengthen financial institutions and external cooperation, the school signed a long-term cooperation agreement with financial institutions, some banks and insurance companies, stock exchanges, regularly selected outstanding students to practice learning department. At the same time, we can also employ the staff of the internship base to do outside school practice instructors, conduct counseling, strengthen the implementation of the school practice, and meet the training of applied Talents in the financial discipline. Practice teaching is an important link in the training of applied financial professionals. In a sense, the quality of the practice teaching determines the training quality of applied financial professionals in the basic situation of classroom teaching convergence. With the private colleges of Finance and economics from inside and outside the classroom and school, more practice, adopt various methods to construct reasonable teaching mode, to stimulate the enthusiasm of students to participate in the financial practice, to enable students to obtain effective practice.

Cooperation of Self-learning and Teaching. A prominent characteristic of compound application oriented financial professionals is their comprehensive ability. The students' comprehensive ability is embodied in the following aspects: self-learning ability, inquiry ability, information integration ability, communication and coordination ability and sustained innovation ability. These abilities need to be trained both within and outside the classroom. The group discussion teaching law cannot only cultivate students' self-learning ability and inquiry ability to solve, can exercise communication skills outside the classroom learning can encourage students to participate in the challenge cup competition, entrepreneurship and innovation of social practice activities such as investigation, linking theory with practice to cultivate the students' ability, and then shaping its sustainable innovation ability. Financial discipline in the formulation of teaching plan, to improve the teaching content and curriculum settings, change the original practice courses, the experiment teaching into financial professional curriculum overall system, take into consideration, to ensure financial experimental hours and total hours than heavy. To ensure the quality of the experimental teaching of the financial specialty and to train the students' practical ability, those experiments require higher. The content of the experiment is more than enough to set up experimental courses independently to ensure the integrity of the teaching activities of the experimental course. The experimental course of financial specialty cannot be separated from the construction of various laboratory platforms, which is also the specific requirement of the financial teaching information network.

Cooperation of Colleges and Enterprises. The basic reason for improving the quality of talent training lies in the reform and perfection of talent training mode. Local colleges and universities should urgently reform their traditional way of relying on their own development concept, organization and management mode. We should continue to promote the reform of the education system and mechanism, the courage to break through the barriers and obstacles to the school and 
external cooperation, actively cooperate with the bank, insurance, securities, Guarantee corporation and other financial institutions to effectively promote the cultivation of innovative talents. cooperation is based on the premise of win-win cooperation. At present, the goal of personnel training in China's colleges and universities is usually based on its own conditions and level of discipline. Therefore, in determining the orientation and training target of personnel training for collaborative innovation, we should not only consider the conditions of colleges and universities, but also consider the conditions and advantages of the participants in the relevant disciplines. From the demand of employers, practice teaching lays a platform for pre-employment, and makes employment units and students have more opportunities to contact each other, and lays a good foundation for more accurate post-employment. In the financial practice teaching in colleges and universities, financial institutions can also invite people related professional practice as teachers, enrich the school practice of teachers, improve the teaching quality of experiment and training; professional, financial, and financial professionals to provide opportunities for students to learn. We should consider the characteristics of the industry sector, and the establishment of collaborative education mechanism in local colleges and universities can take many modes, such as school self-cooperation, outside school coordination, school enterprise synergy and school administration synergy. Based on giving full play to the advantages and conditions of the local colleges and universities, they rely closely on and support other subjects to form synergy effects.

\section{Conclusion}

The training of applied financial talents plays an important role in the development of enterprises in China. Private colleges of finance and economic must provide enough learning resources and development spaces for students to strengthen the integration of various resources. Guided by the targets of the applied talents who have solid theoretical knowledge, rich practical experience and good occupation ethics, the colleges try the best to cultivate more practical financial talents for the enterprises of China.

\section{Acknowledgements}

The paper is the periodical result of the Research Subject of Higher Education and Teaching Reform of Jilin Province named Research on Cooperation Cultivation Model of Financial Applied Talents of Private Colleges of Finance and Economics (Grant No. JZ201501). It is also the periodical result of Research Subject of Higher Education and Teaching named "Research on Class Teaching Method of Finance Based on “Internet + Class Innovation” (Grant No. XZ201602).

\section{References}

[1] Zeng Kanglin, Liu Yuping. Re-discussion on Financial Discipline Construction and Financial Talents Cultivation [J]. Journal of Shanghai Finance University, 2014(3): 5-14.

[2] Song Tong, Yan Jiaqi. Exploration and Analysis of Enhancing Education Quality on Financial Application Talents Training in the New Normal [J]. Journal of Beijing City University, 2015(6): 33-39.

[3] Wu Lina, Li Ming. Research on the training mode of application-oriented financial management talents [J]. Heilongjiang Science, 2016, 7(23): 100-101.

[4] Liu Jialin, Zhou Faming, Wang Xiaojun, Peng Fenwen. Collaborative Reform Research on Application Talent Cultivation of Financial Management Majors Based on Employability Guidance in Local Undergraduate Colleges [J]. Journal of Hunan University of Humanities, Science and Technology, 2013(2): 106-108. 